International Journal of Business and Management Review

Vol.8, No.5, pp.44-67, August 2020

Published by ECRTD-UK

Print ISSN: 2052-6393(Print), Online ISSN: 2052-6407(Online)

\begin{abstract}
DOES INTELLECTUAL CAPITAL EXPLICATE THE RELATIONSHIP
BETWEEN STRATEGIC HUMAN RESOURCES MANAGEMENT AND INNOVATION PERFORMANCE? A CONCEPTUAL FRAMEWORK
\end{abstract}

\author{
Mona Ali Mohamed \\ Assistant lecture of department Human Resources Management, Cairo University, Egypt. \\ Mona_ali@foc.cu.edu.eg. \\ Dr. Gamal Mohamed M. Shehata \\ Professor of department Human Resources Management, Cairo University, Egypt.
}

\begin{abstract}
With increase challenges that face of the organizations, enhancing innovation has become the major strategic objective to survive and grow, accomplishing this objective is by successful in managing firm's intellectual capital, where it is the first driving force for innovation. Hence the organizations pursue to employs strategic HRM approach to the development of the knowledge resources and successful orientation to employees toward reaching the required objective. This approach aims to achieve vertical and horizontal alignment between HRM and organization strategy and designs HRM practices to consistent with the goals of organizations. For that, the current paper adopted a critical analytical approach to developing a conceptual framework about the role of strategic HRM in developing intellectual capital and enhancing innovation based on assumptions of resources-based view (RBV) of the firm.
\end{abstract}

KEYWORDS: intellectual capital, strategic human resources management, innovation, innovation performance, Resource-Based View (RBV)

\title{
INTRODUCTION
}

In today's business world, with the advent of several transitions across the world such as; globalization, environmental changes and accelerating technology. Innovation has become the main force to enhance competitiveness and productivity and enable an organization to survive and continue in the complex, dynamic and changing business environments. Where it is aims to improve the internal structures, processes of business, find the goods and services to meet changes in market requirements and create a competitive position (Donate, Peña, \& Pablo, 2015; Hanifah, Halim, Ahmad, \& Vafaei-zadeh, 2019; Tarhini \& Student, 2017; Wendra, Ernie Tisnawati , Joeliaty, 2019). Thereby, the search about means to boost innovation becomes imperative for the organizations in order to survive and grow. In this regard, RBV indicates can the organizations achieve a sustainable competitive advantage by its internal resources (Barney, 1991; Delery \& Roumpi, 2017). More specifically, intangible resources (e.g. human, social and organizational capital). Which led to attracting attention and shedding light on "intellectual resources" as a means of enhancing innovation 
International Journal of Business and Management Review

Vol.8, No.5, pp.44-67, August 2020

Published by ECRTD-UK

Print ISSN: 2052-6393(Print), Online ISSN: 2052-6407(Online)

and attaining competitive advantage (Agostini, Nosella, \& Filippini, 2017; Tarhini \& Student, 2017).

On the other hand, Strategic HRM is one of the primary means of an organization that its essentially relies on to achieve its short and long-term goals in the dynamic and competitive business environment, it pursues to use integrated methods aimed at developing human resource plans that reflect organizational considerations and works on developing and providing employees with the required knowledge and skills, and achieving maximum benefit from human capital (Naitore, 2019). More specifically, the main purpose of SHRM is clarifying the relationship between human resources management and the organization's strategy and how this relationship affects performance, considering achieving strategic alignment with the organization's goals and objectives and developing a set of consistent and integrated practices, programs and policies that contributes to achieving the strategic goals of the organization (D. K. Gautam, 2015; Gurbuz \& Mert, 2011; Iqba, 2018; Michael Armstrong, 2009). Consequently, SHRM is a new approach to the management of human resources in modern organizations as strategic resources, play a vital role in accomplishing the strategic objectives and create sustainable competitive advantages, this leads to the importance of examining the role of HR on Macro-level (e.g. organizational- level) (Andersen, Cooper, \& Zhu, 2007; Qadeer, 2018; Waiganjo, Kahiri, \& Ph, 2012; Wan-Jing April Chang, 2005; Way \& Johnson, 2005). Accordingly, emerges the importance of current research in utilizing strategic HRM approach as a managerial tool to develop intellectual resources and enhancing innovation.

The studies about the relationship between SHRM and organizational-level outcomes (e.g. operational, financial, quality of service, market share, innovation) were conducted by three major streams: the first stream focuses on the relationship between a set of practices of HRM and performance (e.g. Syed Akhtar, Daniel Z. Ging, 2008; Chen and Huang, 2009; Aryanto, Fontana and Afiff, 2015; Zehir, Üzmez and Y1ldız, 2016), but criticism to this stream was that it focused only on the role of HRM practices in improving performance and this does not reflect the strategic nature of HRM. The second stream focuses on the role of strategic alignment of HRM in improving performance (e.g. Green et al., 2006; Cherrie Jiuhua Zhua, Brian K. Cooper, Stanley Bruce Thomson, 2013; D. K. Gautam, 2015). Hence, this stream increased focus on the strategic alignment of HRM as a managerial function which plays the main role in achieving objectives and improving performance (Jiuhua et al., 2013). However, a scarcity in studies conducted through this stream exists with the focus being only on the direct relationship (see table I). Finally, the third stream seeks to represent the basic purpose of SHRM that encompass both a set of interrelated and consistent practices and strategic alignment of HRM and examine their relationship with performance (e.g. Allui \& Sahni, 2016; Fahim, 2018; Gurbuz \& Mert, 2011). This stream is the closest to the purpose of the current research as will be shown in the following sections.

On the other side, some scholars attempted to explored this relationship through revealing "black box", which aims at identifying intermediate variables that explains this relationship 
International Journal of Business and Management Review

Vol.8, No.5, pp.44-67, August 2020

Published by ECRTD-UK

Print ISSN: 2052-6393(Print), Online ISSN: 2052-6407(Online)

such as; innovative capacity, knowledge management capacity, innovative work behavior (Aryanto et al., 2015; Chen \& Huang, 2009; Fu, Flood, Bosak, Morris, \& O'Regan, 2015). Other studies pointed out that the organization's resources such as; human capital and social capital, play a major role as a mediating variable in explaining this relationship (Donate et al., 2015). With shifting toward a knowledge-based economy, the scholars increased focus on intellectual capital as a critical resource of an organization to gain competitive advantage and achieving organizational effectiveness (Junita, 2016; Kong \& Thomson, 2006; Susan, Saeed, Mohammad, \& Hassan, 2013; D. Wang \& Chen, 2013). The explains the following table (1) some the differences between the studies that were conducted about the relationship between SHRM and performance.

Table (I) the relationship SHRM and performance

\begin{tabular}{|c|c|c|c|c|}
\hline Study & $\begin{array}{l}\text { Dimensions of } \\
\text { SHRM }\end{array}$ & $\begin{array}{l}\text { Mediator } \\
\text { variables }\end{array}$ & $\begin{array}{r}\text { Performance } \\
\text { outcomes } \\
\end{array}$ & Sector \\
\hline $\begin{array}{l}\text { (K. Singh, } \\
\text { 2003). }\end{array}$ & $\begin{array}{l}\text { HR planning, } \\
\text { recruitment and } \\
\text { selection, } \\
\text { evaluation, } \\
\text { compensation, } \\
\text { training and } \\
\text { staffing }\end{array}$ & & $\begin{array}{l}\text { Return of } \\
\text { assets } \\
\text { Sales growth } \\
\text { Price cost } \\
\text { margin }\end{array}$ & $\begin{array}{l}\text { firms listed in } \\
\text { the Business } \\
\text { Today in India }\end{array}$ \\
\hline $\begin{array}{r}\text { Green et ) } \\
\text { (al., } 2006\end{array}$ & $\begin{array}{l}\text { Strategic } \\
\text { alignment of } \\
\text { HRM (vertical } \\
\text { and horizontal } \\
\text { alignment) }\end{array}$ & & $\begin{array}{l}\text { Financial and } \\
\text { marketing } \\
\text { performance }\end{array}$ & $\begin{array}{l}\text { large US } \\
\text { manufacturing } \\
\text { firms }\end{array}$ \\
\hline $\begin{array}{l}\text { (Chen \& } \\
\text { Huang, } \\
\text { 2009) }\end{array}$ & $\begin{array}{l}\text { staffing, } \\
\text { training, } \\
\text { participation, } \\
\text { performance } \\
\text { appraisal, and } \\
\text { compensation }\end{array}$ & $\begin{array}{r}\text { knowledge } \\
\text { management } \\
\text { capacity }\end{array}$ & $\begin{array}{l}\text { innovation } \\
\text { performance }\end{array}$ & $\begin{array}{l}\text { Taiwanese } \\
\text { firms listed }\end{array}$ \\
\hline \begin{tabular}{r}
\multicolumn{2}{c}{ Gurbuz ) } \\
$\& \quad$ Mert, \\
$(2011$
\end{tabular} & $\begin{array}{l}\text { Strategic } \\
\text { alignment } \\
\text { (vertical and } \\
\text { horizontal } \\
\text { alignment) } \\
\text { HR practices }\end{array}$ & & $\begin{array}{l}\text { financial and } \\
\text { market } \\
\text { performance, } \\
\text { operational } \\
\text { performance, } \\
\text { job } \\
\text { satisfaction, } \\
\text { and turnover }\end{array}$ & $\begin{array}{l}\text { Top firms in } \\
\text { the Turkey }\end{array}$ \\
\hline
\end{tabular}


International Journal of Business and Management Review

Vol.8, No.5, pp.44-67, August 2020

Published by ECRTD-UK

Print ISSN: 2052-6393(Print), Online ISSN: 2052-6407(Online)

\begin{tabular}{|c|c|c|c|c|}
\hline $\begin{array}{r}\text { Jiuhua et ) } \\
\text { (al., } 2013\end{array}$ & $\begin{array}{l}\text { Strategic } \\
\text { alignment of } \\
\text { HRM }\end{array}$ & $\begin{array}{l}\text { Organizational } \\
\text { effectiveness }\end{array}$ & $\begin{array}{l}\text { Perceived } \\
\text { financial } \\
\text { performance }\end{array}$ & $\begin{array}{l}\text { Industrial } \\
\text { enterprises in } \\
\text { China }\end{array}$ \\
\hline $\begin{array}{r}\text { Loshali ) } \\
\& \\
\text { Krishnan, } \\
(2013\end{array}$ & $\begin{array}{r}\text { HR planning, } \\
\text { recruitment and } \\
\text { selection, } \\
\text { evaluation, } \\
\text { compensation, } \\
\text { training and } \\
\text { staffing }\end{array}$ & $\begin{array}{l}\text { Transformational } \\
\text { leadership }\end{array}$ & $\begin{array}{l}\text { Market share } \\
\text { growth, sales } \\
\text { growth, } \\
\text { return on } \\
\text { investment, } \\
\text { return on } \\
\text { assets, return } \\
\text { on sales, } \\
\text { overall } \\
\text { performance }\end{array}$ & \begin{tabular}{lr}
\multicolumn{2}{c}{ Different } \\
sectors & in \\
& India
\end{tabular} \\
\hline $\begin{array}{l}\text { Tamer } \\
\text { Khalil } \\
\text { Darwish, } \\
\text { 2013) }\end{array}$ & $\begin{array}{l}\text { Strategic HR } \\
\text { Involvement } \\
\text { HR } \\
\text { devolvement }\end{array}$ & & $\begin{array}{l}\text { Employee } \\
\text { turnover } \\
\text { Return on } \\
\text { assets (ROA) } \\
\text { Return on } \\
\text { equity (ROE) }\end{array}$ & $\begin{array}{l}\text { The financial } \\
\text { sector of } \\
\text { Jordan }\end{array}$ \\
\hline $\begin{array}{r}\text { D. K. }) \\
\text { Gautam, } \\
(2015\end{array}$ & $\begin{array}{r}\text { Strategic } \\
\text { alignment of } \\
\text { HRM }\end{array}$ & & $\begin{array}{l}\text { Product or } \\
\text { service, } \\
\text { quality } \\
\text { Labor } \\
\text { productivity } \\
\text { Innovation } \\
\text { Financial } \\
\text { performance } \\
\text { Employee } \\
\text { satisfaction } \\
\text { Market share } \\
\text { Employee } \\
\text { commitment }\end{array}$ & $\begin{array}{l}\text { listed firms in } \\
\text { Stock } \\
\text { Exchange of } \\
\text { Nepal }\end{array}$ \\
\hline \begin{tabular}{rr}
\multicolumn{2}{r}{ Donate $)$} \\
et $\quad$ al., \\
\\
$(2015$
\end{tabular} & $\begin{array}{l}\text { HRM systems } \\
\text { (high-profile } \\
\text { personal and } \\
\text { collaborative } \\
\text { HRM } \\
\text { practices) }\end{array}$ & $\begin{array}{l}\text { Human capita } \\
\text { Social capital }\end{array}$ & $\begin{array}{l}\text { Innovation } \\
\text { capabilities }\end{array}$ & $\begin{array}{r}\text { Technological } \\
\text { companies in } \\
\text { Spain }\end{array}$ \\
\hline $\begin{array}{r}\text { Duanxu, ) } \\
\text { Shuai, } \\
\text { Wang, \& }\end{array}$ & $\begin{array}{l}\text { Comprehensive } \\
\text { staffing, } \\
\text { extensive }\end{array}$ & $\begin{array}{r}\text { Intellectual } \\
\text { capital }\end{array}$ & $\begin{array}{l}\text { Innovation } \\
\text { capabilities }\end{array}$ & $\begin{array}{l}\text { High- } \\
\text { technology } \\
\text { and non-high- }\end{array}$ \\
\hline
\end{tabular}


International Journal of Business and Management Review

Vol.8, No.5, pp.44-67, August 2020

Published by ECRTD-UK

Print ISSN: 2052-6393(Print), Online ISSN: 2052-6407(Online)

\begin{tabular}{|l|l|l|l|l|}
\hline $\begin{array}{l}\text { Chen, } \\
(2013\end{array}$ & $\begin{array}{l}\text { training, } \\
\text { knowledge- } \\
\text { and skill-based } \\
\text { reward } \\
\text { systems, } \\
\text { teamwork and } \\
\text { employee } \\
\text { participation. }\end{array}$ & & & $\begin{array}{l}\text { technology } \\
\text { industries in } \\
\text { China }\end{array}$ \\
\hline $\begin{array}{l}\text { (Zehir, } \\
\text { Gurol, } \\
\text { Karaboga, } \\
\text { \& Kole, } \\
\text { 2016) }\end{array}$ & $\begin{array}{l}\text { SHRM } \\
\text { practices }\end{array}$ & $\begin{array}{r}\text { Entrepreneurial } \\
\text { Orientation }\end{array}$ & $\begin{array}{l}\text { Financial } \\
\text { performance } \\
\text { Employee } \\
\text { performance }\end{array}$ & $\begin{array}{l}317 \text { Islamic } \\
\text { Bank } \\
\text { managers in } \\
\text { Turkey in }\end{array}$ \\
\hline
\end{tabular}

Despite finding the many studies that argue the direct or indirect relationship between SHRM and performance. Still as yet, the argument related to "How can SHRM contribute to achieving strategic objectives of the organization and improve performance"? In need of further clarification (Fahim, 2018; Nigam, Nongmaithem, Sharma, \& Tripathi, 2011; WanJing April Chang, 2005; Way \& Johnson, 2005; Wright, Nyberg, \& Ployhart, 2018). Consequently, in this respect some research gaps have been identified involving; 1) Despite the strategic nature of SHRM, many studies argue in SHRM literature only the relationship between a set of HRM practices and performance (Arunprasad, 2017; Syed Akhtar, Daniel Z. Ging, 2008; Wright \& Ulrich, 2017), whereas strategic alignment of HRM is not getting sufficient attention as a major dimension of SHRM (D. K. Gautam, 2015; Jiuhua et al., 2013; Martinson \& De Leon, 2018). So, we intend to provide a broader and more complete picture of the relationship between SHRM and performance by adopting the conceptual logic of SHRM that includes ; Strategic alignment of HRM and adopting interrelated and internally consistent practices (Andersen et al., 2007; Michael Armstrong, 2009). 2) The need for more studies about the relationship between HR and innovation, given to the importance of innovation as a non-financial measure to evaluate performance in the modern economy (Fu et al., 2015), this study explores the relationship between SHRM and innovation performance. 3) Although a large number of prior studies have investigated the mediating mechanisms between SHRM and innovation (Aryanto et al., 2015; Chen \& Huang, 2009; Zehir, Üzmez, et al., 2016), there is a lack of explaining the role of intellectual capital as a mediator in the this relationship. 5) Though RBV forming the theoretical and empirical basis for SHRM and aiming to narrow the bridge between 'Micro - Macro' levels for the organization (Delery \& Roumpi, 2017; Peccei, 2019; Renkema, Meijerink, \& Bondarouk, 2017; Wright, Dunford, \& Snell, 2001), there is scarcity in the studies that reflect the assumptions of this theory (John E. Delery, 2015; Nigam et al., 2011; Wright et al., 2001). In light of the above, our paper is motivated by two considerations: First; there is rarity of literature that investigates the association between SHRM, Intellectual capital and innovation performance. Secondly; we place great emphasis on the strategic nature of the relationship between HRM and performance through the adoption of strategic alignment of 
International Journal of Business and Management Review

Vol.8, No.5, pp.44-67, August 2020

Published by ECRTD-UK

Print ISSN: 2052-6393(Print), Online ISSN: 2052-6407(Online)

HRM and strategic HR orientation as dimensions of SHRM, where the focus of most of the previous studies in strategic HRM on the relationship between HRM practices and performance (John E. Delery, 2015).

Thereby, in order to fill these gaps and to attempt to respond to studies that encourage the importance of examining the role of intermediate variables in strategic HRM field (K. Jiang, Takeuchi, \& Lepak, 2013; John E. Delery, 2015), our main aim is constructing a theoretical model to explore the role of SHRM in developing intellectual capital as one of the organization's resources "Micro-level" and its relationship with innovation performance as one of the organization's outcomes "Macro-level". We support these relationships based on RBV assumptions, which states that internal resources (e.g. intellectual capital) play a main role in improving innovation performance and gaining a competitive advantage" in the case of being a valuable, rare, inimitable and non-substitutable (Bal, 2013; K. Jiang et al., 2013; John E. Delery, 2015). To realize this aim this paper includes the following sub-objectives; 1) it provides an analytical overview of the main theoretical perspectives that have been used to explain the major concepts (i.e. SHRM, intellectual capital and innovation). 2) A critical review of prior studies explicating the relation between SHRM and innovation performance. 3) A critical review of prior studies that explored the role of intellectual capital as a driver to innovation performance. 4) Formulating the proposed conceptual framework to highlight the link between SHRM, intellectual capital and innovation.

The major contributions of this paper include; 1) providing a more logical explanation of the mechanisms through which the strategic HRM impact innovation performance. 2) Extending discussion about mediating mechanisms to the relationship between strategic HRM innovation performance by exploring the role of "intellectual capital" as a mediator for this relationship. 3) It is expected this study that contribute to the broader knowledge of HRM studies in general and strategic HRM literature in particular, through shedding light on the importance of integration between HRM and strategic management as a tool to achieve strategic objectives. As well as, showing the importance of intermediate variables in explicating the relationship between HRM and performance.

To achieve the purpose of current research, the next section reviews the theoretical concepts relevant to the current research (i.e. Strategic HRM, Intellectual capital and innovation) available in the literature. This is followed by a section on a previous literature review that examined the relationships between these concepts. Then a section on developing the theoretical model that explains the proposed relationship between these concepts and finally, the study conclusions, limitations of the study and future research suggestions.

\section{THEORTICAL BACKGROUD}

\section{Strategic Human Resources Management}

The term strategic HRM appeared to clarify the strategic role of HRM in realizing organizational effectiveness, this is according to two major assumptions; 1) the integration 
International Journal of Business and Management Review

Vol.8, No.5, pp.44-67, August 2020

Published by ECRTD-UK

Print ISSN: 2052-6393(Print), Online ISSN: 2052-6407(Online)

between HRM and the organization's objectives, 2) the exploration of the role of HR in improving organizational performance (John E. Delery, 2015; Schuler \& Jackson, 2005). In this context, SHRM has been defined according to different perspectives such as; from the founders of this concept Wright and McMahan (1992, p298), they defined "Strategic HRM" as; "the pattern of planned human resource deployments and activities intended to enable an organization to achieve its goal", according to this definition strategic alignment can be divided to two dimensions; vertical alignment; which highlights the link between HRM and the organization's strategy. Horizontal alignment; which suggests that HRM practices are interrelated and internally consistent (Wright, P.M., and McMahan, 1992). From another perspective, Allui \& Sahni (2016, P363) suggests that SHRM is "the development and execution of a set of proactive HR policies/practices that ensure that the human capital of an organization contributes to the achievement of its objectives". Consequently, explains SHRM according to this definition the proactive and executive side of HRM (Allui \& Sahni, 2016). In the context of the current paper, strategic HRM or SHRM defined as "an approach for human resources management aims to achieve the strategic alignment of human resources management with the goals and strategies of the organization, and orientation human resources towards achieving them through the use of a set of practices that are consistent with the organization strategy in a way that leads to the development of intellectual capital resources and improves its innovation performance".

From the critical and controversial issues among researchers in SHRM literature is to determine the mechanisms used to measures the strategic HRM to examine its relationship with performance. In this respect, researchers are divided between two perspectives; systematic perspective and strategic perspective (Saridakis, Lai, \& Cooper, 2016; S. Singh, Darwish, Costa, \& Anderson, 2012; Tamer Khalil Darwish, 2013).The first; indicates a set of specific and integrated practices that contribute to improving performance and implementation of the organization's strategy (Boon et al., 2018; S. Singh et al., 2012; Tamer Khalil Darwish, 2013). This perspective received the most attention from scholars and academics in strategic HRM literature in accordance with various terms such as; "best practices, high-performance work systems, high involvement practices, high commitment practices and performance-oriented work systems" (Singh et al., 2012; Wright and Ulrich, 2017). The second; suggests achieving the vertical and horizontal alignment of human resources management and the organization's strategy towards contributing to accomplishing strategic goals such as; increasing profitability, growth and market share (S. Singh et al., 2012; Tamer Khalil Darwish, 2013). From the concepts extensively used through this perspective; Strategic alignment of HRM, Strategic HR development (Budhwar, 2000; Green et al., 2006; Tamer Khalil Darwish, 2013) and Strategic HR orientation (Loshali \& Krishnan, 2013; K. Singh, 2003). In general, with increased research in the SHRM domain, we explain through the following figure (1) the more important research issues that attracts attention of academics, scholars and practitioners in the filed strategic HRM over the past decade (K. Jiang et al., 2013; John E. Delery, 2015; K. Singh, 2003; Wright, P.M., and McMahan, 1992; Wright \& Ulrich, 2017). Subsequently, pinpoints the sides relevant to the current research and that will represent the focus of discussion in the context of this research. 
International Journal of Business and Management Review

Vol.8, No.5, pp.44-67, August 2020

Published by ECRTD-UK

Print ISSN: 2052-6393(Print), Online ISSN: 2052-6407(Online)

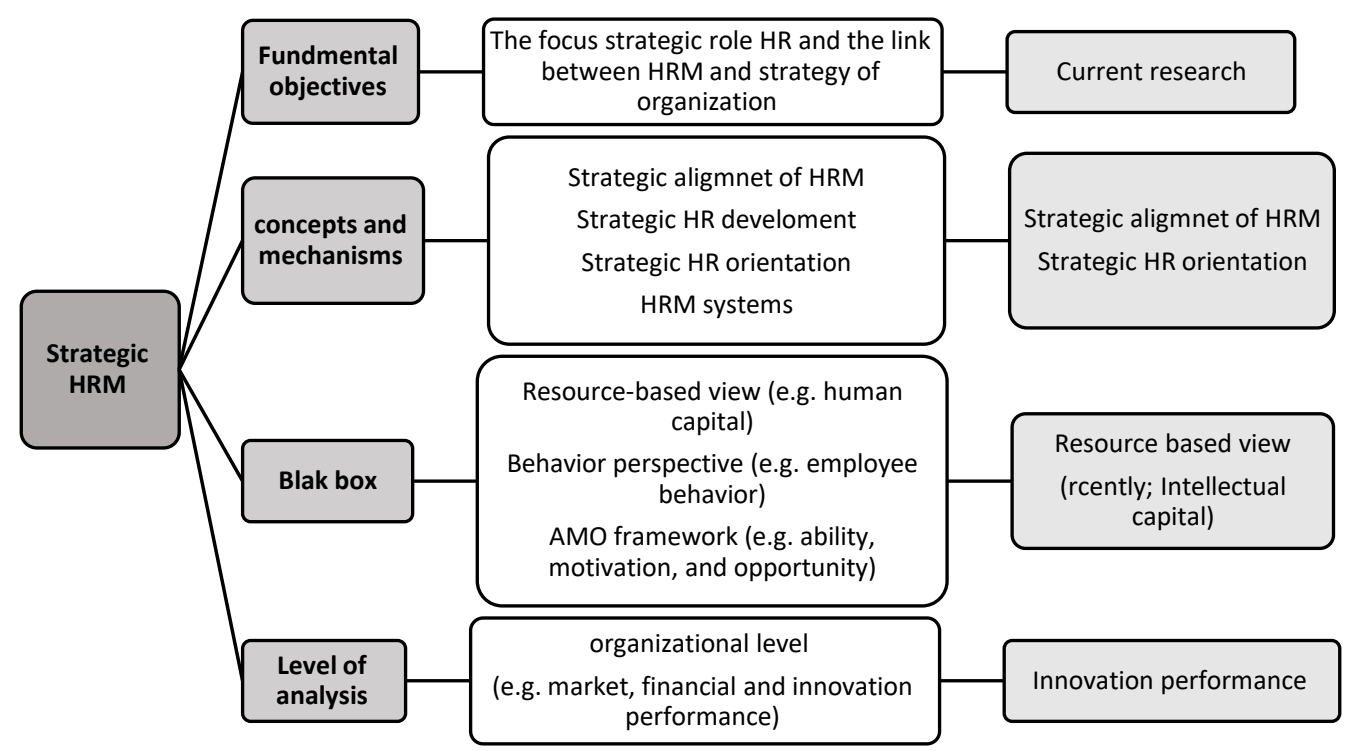

Figure 1: foundation of strategic HRM

In the context of the present paper, we specifically focus on two dimensions of SHRM ; Strategic alignment of HRM; is the most important aspect of strategic HRM literature (Ekhsan Abang Othman, 2009; D. K. Gautam, 2015; Iqba, 2018; Jiuhua et al., 2013). It is defined according to Qadeer (2016, P3) as "the extent to which human resources management linked to the organization's strategy and considered a part of it". In other words, it refers to involving HRM in the formulation and implementation strategy of the organization and the alignment of HRM with the strategic objectives of the organization (Andersen et al., 2007; Budhwar, 2000). As well as, strategic HR orientation; another major aspect of SHRM that includes the design and implementation of an internally consistent set of policies and practice that is aimed at the orientation of human resources towards achieving strategic objectives and the creation of competitive advantage (Iqba, 2018; Nigam et al., 2011; Wan-Jing April Chang, 2005). The focus on these two dimensions as mechanisms to SHRM is a result for ; 1) there is scarcity in studies that examine these two dimensions and their relationship with intellectual capital and innovation, 2) in addition to that these twodimensions are the most representative to the strategic nature of HRM (Andersen et al., 2007; D. K. Gautam, 2015; Green et al., 2006; Jiuhua et al., 2013; John E. Delery, 2015; Michael Armstrong, 2009; K. Singh, 2003). In subsequent sections, we will denote the role of these two dimensions in improving performance. Particularly, innovation performance.

\section{Intellectual Capital}

In the new economy based on knowledge and information, IC became one of the main productions factors that can lead organizations to adaptation, survival, and increasing competitiveness in constantly evolving markets (Delgado-Verde, Martín-De Castro, \& Amores-Salvadó, 2016; Ozkan, Cakan, \& Kayacan, 2017), and a major driver to achieve 
International Journal of Business and Management Review

Vol.8, No.5, pp.44-67, August 2020

Published by ECRTD-UK

Print ISSN: 2052-6393(Print), Online ISSN: 2052-6407(Online)

innovation and value creation (Delgado-Verde et al., 2016; Karchegani, Sofian, \& Amin, 2013). Where it involves the employees' expertise, abilities, interactions and skills, the organizational resources, programs, procedures and the external relationships of the organization with parties such as, customer and suppliers, etc. (Agostini et al., 2017; Wendra , Ernie Tisnawati , Joeliaty, 2019). In this regard, intellectual capital can be defined as "a combination of an organization's human, organizational and rational resources and activities" (Agostini et al., 2017, P2). Also, can be characterized as "a set of knowledge resources that organizations utilize to gain a competitive advantage" (Youndt, Subramaniam, \& Snell, 2004, P2). thereby; Intellectual capital is becoming increasingly important as a strategic resource for promoting positive outcomes on the level of an organization such as; competitive advantage and value creation (Chahal \& Bakshi, 2015; Rezende, Correia, \& Gomes, 2017; Yaseen, Dajani, \& Hasan, 2016), operational and financial performance (Dženopoljac, Janoševic, \& Bontis, 2016; Pedro, Leitão, \& Alves, 2018; Z. Wang, Wang, Cao, \& Ye, 2016) and innovation performance (Agostini et al., 2017; Andreeva, Garanina, \& Andreeva, 2016; Cabello-medina, López-cabrales, \& Valle-, 2011).

In general, the consensus of scholars that IC serves as the driver to the various outcomes of performance by three subtypes (Human, Organizational, Social capital), that are widely accepted among researchers (Hussinki, Ritala, Vanhala, \& Kianto, 2017; Ozkan et al., 2017; Yaseen et al., 2016; Youndt et al., 2004; Yuqian Han, 2015): Human capital; involves capabilities related to the people within the organization (i.e. employees' tacit knowledge, skills, experience and their attitudes), and these resources are not owned by an organization, but possessed by employees (Hui-Ying Zhang, 2015; Ozkan et al., 2017; Yaseen et al., 2016). Organizational capital; represents resources stored in the systems, programs and databases of an organization (i.e. codified knowledge, procedures, processes, goodwill, patents, and culture), and is remaining in an organization even when the employees leave the workplace (Hussinki et al., 2017; Ozkan et al., 2017; Yaseen et al., 2016). Social capital; represents the value derived from the relationship with customers, suppliers, strategic partners and shareholders (Allameh, 2018; Hui-Ying Zhang, 2015; Yaseen et al., 2016). According to illustrate above, this paper proposes that IC can be defined IC as "all knowledge resources that encompass (HC, SC and $O C$ ) and serve as the main driver to enhancing innovation to survive organizations and achieve sustained competitive advantage". The figure (2) shows the theoretical framework adopted in the current research.

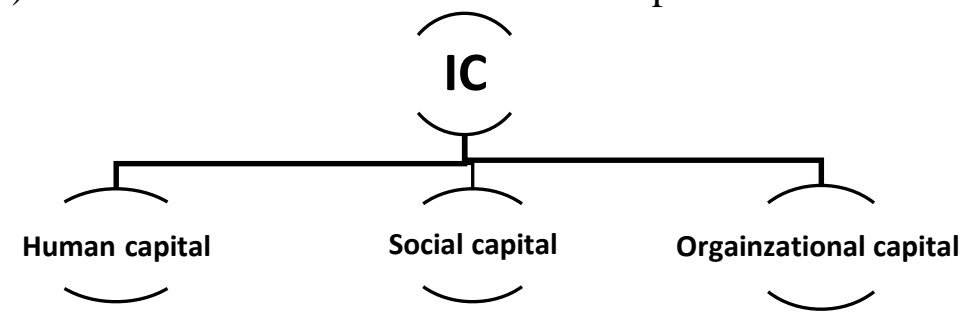

Figure 2: Theoretical framework of IC

Source; adopted from (Youndt et al., 2004) 
International Journal of Business and Management Review

Vol.8, No.5, pp.44-67, August 2020

Published by ECRTD-UK

Print ISSN: 2052-6393(Print), Online ISSN: 2052-6407(Online)

\section{Innovation Performance}

From the trends that reflect the strategic transition of HRM is the emphasis on the macrolevel of organization. In this respect, scholars in SHRM studies classified the organizational outcomes into three major groups; HR outcomes (e.g. skills, capabilities, job satisfaction and commitment), operational outcomes (e.g. innovation and productivity) and financial outcomes (e.g. ROA, EOA, sales growth and profitability) (K. Jiang, Lepak, Hu, \& Baer, 2012; Madera, Dawson, \& Guchait, 2016; Naitore, 2019; Way \& Johnson, 2005; Wright, Gardner, \& Moynihan, 2003). In the context of the current research we will emphasize the strategic role of HR on an organizational level. Specifically, innovation as one of outcomes of performance for the following reasons; firstly; the innovation is the first outcome of developing intellectual capital (Abdal et al., 2017; McDowell, Peake, Coder, \& Harris, 2018), secondly; the increasing importance of innovation as a major force for both the public and private sector to create value and gain sustained competitive advantage (Chen \& Huang, 2009; Sözbilir, 2018). Thirdly, there is a lack in studies examining the relationship between SHRM and innovation performance.

Despite the increasing importance of innovation as a major determinant to the success of modern organizations in managerial sciences in general, there is no agreement between researchers about the definition of innovation due to its complex nature and being a multidimensional concept (Allameh, 2018; Jonc, 2015). From an organizational perspective, innovation is a significant source of sustainable competitive advantage via developing and renewing products and administrative structures (C. J. Chen \& Huang, 2009, P4). In other words, Ceylan (2013, P4) defines innovation as a tool for changing by providing new ideas to develop and improve the different areas of work of the organization such as; products, systems, programs and processes. Also, Lu, Zhu, \& Bao (2015, P7) mentions it as a multistage process involving creating new ideas from employees, promoting and implementing those ideas using existing resources. In the current research we define innovation as "one of the organizational performance outcomes that reflect the organization's ability to provide and developing products and administrative practices within an organization".

\section{LITERATURE REVIEW}

In this section, we attempt to explain the relationship between (1) SHRM and innovation, (2) intellectual capital and innovation and (3) the proposed theoretical framework.

\section{Strategic Human Resources Management and Innovation Performance}

Nowadays, many modern organizations try to utilize strategic HRM as an approach to managing human resources to gain a competitive advantage (Haque, 2018), through two crucial mechanisms include; 1) achieving horizontal and vertical alignment of human resources management with the goals and strategies of the organization; and 2) providing a set of consistent and integrated human resources practices that contribute to providing individual and collective needs of employees and achieving the objectives of the organization. Which in turn, leads to providing employees with skills, competencies, high 
International Journal of Business and Management Review

Vol.8, No.5, pp.44-67, August 2020

Published by ECRTD-UK

Print ISSN: 2052-6393(Print), Online ISSN: 2052-6407(Online)

motivation, commitment, and interconnection with the organization. Thereby, increase the organizational capacity and creates a competitive advantage for it (Andersen et al., 2007; John E. Delery, 2015; Michael Armstrong, 2009). For that, through this part we hope to explain the role of strategic alignment of HRM and strategic HR orientation as mechanisms of SHRM in improving innovation performance.

Strategic alignment of HRM plays a major role in dealing with complex organizational issues such as; achieving the delicate balance between human, financial and technological resources when establishing objectives; and operationalizing strategic contribution of HR (D. K. Gautam, 2015). Besides that, it acts as a driver to improve performance and organizational success by, involving HR manager in strategic planning (Ekhsan Abang Othman, 2009; Tamer Khalil Darwish, 2013), looking at the HR manager as strategic partners who should be involved in strategic decision making and business strategy formulation and implementation (Andersen et al., 2007; D. K. Gautam, 2015). Which in turn, leads to enhanced competence, increases the efficiency and effectiveness of organization and leads to, higher job performance, and faster innovation (Andersen et al., 2007; Tamer Khalil Darwish, 2013). In this context scholars have been attempting to establish a meaningful link between the strategic alignment of HRM and performance by empirically examining. Green et al., (2006) the relationship between the vertical and horizontal fit of SHRM and performance within large US manufacturing firms. Results indicate to that the organization that achieve strategic alignment between HRM and organization strategy produce more committed and satisfied employees and this in turn, leads to improving individual performance and organization performance. Likewise (D. Gautam, 2015; Jiuhua et al., 2013). Cherrie Jiuhua Zhua, Brian K. Cooper, Stanley Bruce Thomson (2013) argues organizational effectiveness as a mediator in the relationship between the strategic alignment of HRM and performance in state-owned and private (domestic and foreign-invested) enterprises in China. The results demonstrate the positive relationship between the strategic alignment of HRM and organizational effectiveness and performance. Also, D. K. Gautam, (2015) through comparison between the high and low strategic alignment of the organization, suggested that organizations with high strategic alignment of HRM achieve better performance outcomes such as; quality of product or service, level of productivity, financial performance, employee satisfaction, rate of innovation, employee commitment and market share. Although, these three previous studies examined an important dimension of SHRM (i.e. strategic alignment of HRM) and its relationship with performance. But it ignored innovation as one of the outcomes of performance, focusing on the manufacturing sector and on listed firms and ignored the service sector. Hence, we need to investigate the relationship between the strategic alignment of HRM and innovation as a major dimension to many organizations to gain competitive advantage within the service sector.

Strategic HR orientation; according to RBV from the strategic tasks of HRM is the development of human resources to become a source to competitive advantage and considering HRM practices as mechanisms to enhancing innovation performance (N. Singh, 2018). In the support of this idea, Bal (2013) reinforce that HRM practices represent 
International Journal of Business and Management Review

Vol.8, No.5, pp.44-67, August 2020

Published by ECRTD-UK

Print ISSN: 2052-6393(Print), Online ISSN: 2052-6407(Online)

infrastructure elements of strategic HRM which organization utilize in the orientation of human resources to gain competitive advantage. In addition to that investment in HRM practices contribute to achieving elements of sustainable competitive advantage that were found in RBV and includes; value, rareness, non-substitutability, and inimitability. Which in turn, leads to increased innovation (Shaw et al., 2013). In line with this rationale, SHRM focuses through this dimension on internally consistent practices that are aligned with the organization's strategy, to enhance employees' capabilities (knowledge, skills, abilities, etc.), and provide the workforce with highly committed, motivated, and skilled to achieve the strategic objectives (Allui \& Sahni, 2016; Susan et al., 2013). The reviewed literature has revealed mixed results regarding the relationship between strategic HR orientation and performance. K. Singh (2003) indicate that there is a positive relationship between (HR planning, staffing, training, compensation and evaluation) and organizational performance. HR planning is vital in SHRM, where it helps to match skills, abilities and expertise of employees with organizational objectives, which in turn leads to improved performance (Bal, 2013; K. Singh, 2003). C. J. Chen \& Huang (2009) suggests that (staffing, employee participation, performance appraisal, and compensation) represents a set of practices that rely on the organizations to develop knowledge, skills and expertise of employees as drivers to enhancing innovation. Consequently, there are positive relationship between these practices and innovation performance. In support of this notion also, Bal (2013) indicated that HR practices play a supportive role in accomplishing innovation when oriented for the future, work in a manner aligned with the overall business plan in the organization and design according to employees' needs. In other context within the Indonesian software industry, Aryanto et al. (2015) reveals that SHRM through a set of practices can be a predictor to innovation, where human resources are considered as a critical element in achieving innovation.

In sum, despite several studies that examined the relationship between SHRM and performance, there is still a scarcity of empirical studies related to these two concepts (strategic alignment of HRM and strategic HR orientation) as dimensions of strategic HRM and their relations to innovation as one of outcomes of performance. So, based on the above arguments we assumed that SHRM by the strategic alignment of HRM and strategic HR orientation will lead to enhancing the innovation performance. Consequently, we formulate our first proposition as follows:

Proposition 1; will applying strategic human resources management by (Strategic alignment of HRM and Strategic HR orientation) lead to a higher level of innovation performance.

\section{Intellectual Capital and Innovation Performance}

In regards to how IC is a main a source to innovation, (Mir Dost, Yuosre F. Badir, Zeeshan Ali, 2016) argues that IC is one of the most important intangible resources that act as an essential determinant to achieving innovation. In support of this notion, (Karchegani et al., 2013) indicates that IC and innovation are two major resources to achieve a competitive 
International Journal of Business and Management Review

Vol.8, No.5, pp.44-67, August 2020

Published by ECRTD-UK

Print ISSN: 2052-6393(Print), Online ISSN: 2052-6407(Online)

advantage and increase firm performance. Thus, the company's ability to invest, manage, develop and maintain intellectual capital components leads to increased innovation as a vital driver to gain a competitive advantage for the organization. According to RBV, IC is the more important strategic resource for assisting an organization on achieving sustainable competitive advantage through its three dimensions (Yuqian Han, 2015). Human capital is a critical dimension to IC and a supportive factor to innovation by knowledge, skills and abilities that are owned by employees (Kalkan, Bozkurt, \& Arman, 2014; Mir Dost, Yuosre F. Badir, Zeeshan Ali, 2016; Yuqian Han, 2015), and which contributes to the development of new ideas in the organization (McDowell et al., 2018). Regarding organizational capital, it works as a driver of innovation by knowledge accumulated in the organization systems, database and procedures...etc., and that contribute to developing human capital and increasing customer satisfaction (Farouk, Elanain, Obeidat, \& Al-nahyan, 2016). Considering the importance of external knowledge in innovation (Wendra, Ernie Tisnawati , Joeliaty, 2019), emerges the role of social capital to enhancing innovation via interaction, sharing knowledge and ideas between all stakeholders such as; suppliers, customers and any other parties relevant to the organization (Cabello-medina et al., 2011; Mir Dost, Yuosre F. Badir, Zeeshan Ali, 2016; Youndt et al., 2004). As well as, Agostini et al. (2017) argues that the strong and close relationships between stakeholders and organization have a direct positive effect on innovation performance.

Thus, IC is a very crucial resource to enhancing innovation, this is supported by several previous studies such as; (Farouk et al., 2016) through theoretical review about the relationship between IC and innovation indicate which results that almost all studies suggested that IC and its elements represents crucial drivers to innovation, with difference in the importance of this relation according to activities, strategies, and structures of the organizations. As well, Agostini et al. (2017) found a positive relationship between IC and innovation performance of SMEs. Is due to that the organization can effectively manage of IC via investing in training, work design and other HRM activities to achieve high innovation performance compared to others that don't do this. In the same context also Abdal et al. (2017) pointed out that IC is an essential input to enhancing innovation within SMEs. Specifically, human capital and social capital, while structural capital is less important to innovation. In a different context, Mir Dost, Yuosre F. Badir, Zeeshan Ali (2016) investigated the separate and interrelated effects to dimensions of IC on generation and adoption of innovations within chemical organizations. The results reveal that both social and organizational capital have significantly positive impacts on innovation, on contrast human capital is less significant, but when achieving the interaction between three dimensions shows significantly positive results. In clarifying this Cabello-Medina et al. (2011) indicated that human capital characteristics (KSAs) become superseded over time. Therefore the organization acts to its enhancing via social capital and HRM practices. Whereas, Yuqian Han (2015) from within the manufacturing sector in china postulates the positive relationship between IC and innovation. Thereby, seeks an organization to develop IC by continuous training of employees (human capital), develop and enhance the 
International Journal of Business and Management Review

Vol.8, No.5, pp.44-67, August 2020

Published by ECRTD-UK

Print ISSN: 2052-6393(Print), Online ISSN: 2052-6407(Online)

relationships with stakeholders (social capital) and develop substructure of the organization database, systems, process and procedures...etc. (Organizational capital).

In sum, intellectual capital is the predictor for innovation performance. However the focus of most studies was directed on the individual impact of IC dimensions and ignored the interaction impact of IC dimensions on innovation. For this, the current research aims at understanding the way intellectual capital influence innovation performance through examining the separate and interrelated impacts of the various aspects of intellectual capital (human capital, social capital and organizational capital) on innovation. Hence, our second proposition stipulates.

\section{Proposition 2; intellectual capital and its components (HC, SC and OC) contribute to enhancing innovation performance.}

\section{RBV-Based Mediation Framework}

In another side, one of the critical substantive issues in strategic HRM literature is the "black box" issue to determine mechanisms used to explain the relationship between strategic HRM and performance. From the most popular approaches in regard; the behavioral approach; suggests that HRM contributes to improving organizational outcomes by developing human resources' positive behaviors and orienting them towards achieving the business goals and objectives (K. Jiang et al., 2012, 2013; Katou, 2017; Messersmith, Lepak, \& Gould-williams, 2011). Thereby, this approach emphasizes the role of employee behaviors as a mediator, resulting in the development of AMO framework, that postulate enhancing productive behavior of employees via the development of abilities, motivation and opportunity for employees (Delery \& Roumpi, 2017).

And competencies approach ( $R B V)$; is relied essentially on RBV assumptions and suggested that HRM is a source to competitive advantage by its role of utilizing HRs and providing desirable behaviors, which leads to increased organizational efficiency (Gannon, Roper, \& Doherty, 2015; Junita, 2016; Nigam et al., 2011; Tamer Khalil Darwish, 2013; Way \& Johnson, 2005; Wright et al., 2001). In other words, HR practices contribute to achieving organizational objectives through increasing knowledge, skills and abilities of employees and that is the human capital (K. Jiang et al., 2012; Katou, 2017). Eventually, researchers rely on one of these approaches to explore the role of HRM on the organizational level (Jiang et al., 2012). Consequently, according to objectives of the current research to explaining the role of intellectual capital as a mediator to the relationship between SHRM and innovation performance (Wright et al., 2001).We adopted RBV as a major tool to clarify this relationship, based on the argument that this approach is shifting interest towards internal organizational resources as sources to gaining a sustainable competitive advantage when it is rare, valuable and non-substitutable. As a result, according to RBV the organization's efforts to improve performance are dependent on internal resources such as (human, organizational and social capital), which is known as the intellectual capital (Junita, 2016). 
International Journal of Business and Management Review

Vol.8, No.5, pp.44-67, August 2020

Published by ECRTD-UK

Print ISSN: 2052-6393(Print), Online ISSN: 2052-6407(Online)

In support of the preceding discussion, Omerzel \& Jurdana (2016) indicates that IC is one of the more important intangible resources within an organization and one of the vital inputs to achieve innovation and provide value-added to stakeholders. Hence, the organization's ability to achieve innovation relies on its intellectual capital. In response, the trend towards the development of HRM has increased as means to enhancing intellectual capital as a major source of generating innovation (Donate et al., 2015). This is consistent with Becker \& Huselid (2006) who indicated that the internally consistent HRM practices that support organizational strategy, are a major means to attract, motivate and develop intellectual capital to gain a sustainable competitive advantage. Additionally to (Haque, 2018; Youndt et al., 2004) who indicate that SHRM plays a major role in developing human and social capital by enhancing skills, knowledge and abilities of employees and network of relationship. Consequently, scholars have begun to investigate the importance of development IC as a vital factor to achieve a sustained competitive advantage and improve performance, by investing in employees' knowledge, skills and abilities, processes, systems and internal and external relationships in the organization, which in turn leads to enhancing innovation (McDowell et al., 2018).

In attempting to respond to this are conducted several empirical studies in this regard (e.g. Wright and McMahan, 2011; Chowhan, 2016; Madera et al., 2016) which indicate that human capital mediate the relationship between HRM and organizational outcomes, through knowledge and skills and capabilities that enhance performance and strengthen efficiency and competitiveness. In support of this notion, most scholars of strategic HRM have reached an agreement that human capital serves as one of the important mediators of the relationship between HRM practices and firm performance (John E. Delery, 2015). Whereas, other studies suggest that in addition to human capital they postulates that social capital mediates this relationship, by achieving trust, coordination and knowledge exchange between all stakeholders (Youndt et al., 2004; Jiang, Wang and Zhao, 2012; Shaw et al., 2013). In support of this notion Donate et al., (2015) conducted a study that contribute to strategic HRM literature by exploring the role of human and social capital in explaining the relationship between HRM systems and innovation. results indicate that HR managers should be the most interested with the development of human and social capital as the strategic resources via the employment of the set of practices that act as systems such as (selective staffing, training, high compensation systems, broad job design, empowerment, teamwork), which in turn lead to improving innovation. More recently, some studies have surfaced that examine intellectual capital such as; Wang and Chen (2013) who explored the role of intellectual capital as a mediator to the causal relationship between HPWS as one of the mechanisms of the systematic perspective in SHRM literature and innovation performance, the results show the supportive role IC plays in explaining a relationship between HPWSs and innovation, whereas the direct relationship between HPWSs and innovation does not exist.

Despite this progress in strategic HRM literature, we find that most of these studies are done with a focus mostly on the systemic perspective by exploring the relationship between HRM 
International Journal of Business and Management Review

Vol.8, No.5, pp.44-67, August 2020

Published by ECRTD-UK

Print ISSN: 2052-6393(Print), Online ISSN: 2052-6407(Online)

systems and innovation performance (Donate et al., 2015; D. Wang \& Chen, 2013). Also, (Becker and Huselid, 2006; Paauwe, 2009; Madera et al., 2016) indicate that approximately 300 articles are published in strategic HRM literature about the relationship between HRM systems and performance. However, still this relation is not clear. Which provoked researchers to employ "black box" concept to examining the mediating variables that explain this relation (e.g. human capital and social capital). Consequently, explicating the role mediating mechanisms in strategic HRM, still a research issue that interests academics and researchers (K. Jiang et al., 2013). Moreover, there is a scarcity in the studies that focus on the strategic perspective of SHRM and innovation performance.

In sum, based on RBV assumptions and previous study results illustrated above, we aim to explore the role of SHRM through two dimensions; strategic alignment of HRM and strategic HR orientation in increasing innovation performance. And examining the role intellectual capital (i.e. human, organizational and social capital) as a mediator in the explication of this relationship. Eventually, hopefully with this paper we extend the attention to the transition from just the development of human capital characteristics (KSAs) as a vital issue of strategic HRM to the development of intellectual capital (i.e. HC, SC and OC) as a resource of knowledge on the level of individual, collective and the organization. Figure 2 exhibits the suggested conceptual framework to the relationship between SHRM, intellectual capital and innovation performance. Hence, our third and fourth propositions can be formulated as follows;

Proposition 3: it is expected that employing SHRM approach leads to increased intellectual capital.

Proposition 4: it is expected that the intellectual capital explains the relationship between SHRM and innovation performance.

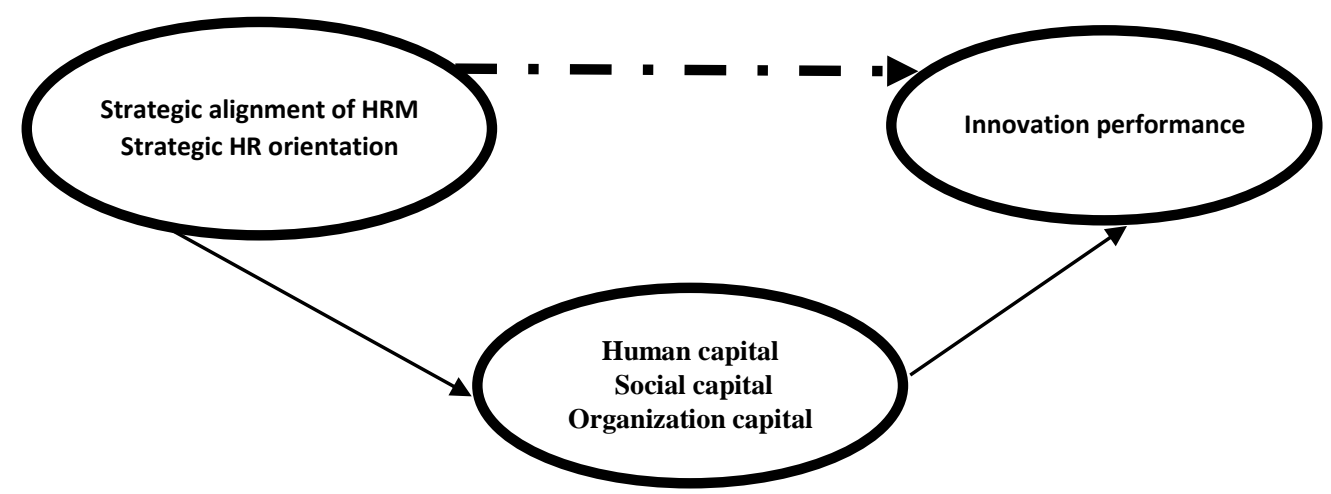

Figure 3: Conceptual model

In sum, our model proposes that achieving vertical and horizontal alignment of HRM with the strategy of an organization through; the involvement of HR managers in decision making, strategic planning and formulation and implementation of the organization's 
International Journal of Business and Management Review

Vol.8, No.5, pp.44-67, August 2020

Published by ECRTD-UK

Print ISSN: 2052-6393(Print), Online ISSN: 2052-6407(Online)

strategy. In addition to design and the execution of a set of consistent HRM practices and the alignment with the organization's strategy is expected to lead to a high level of human, organizational and social capital, which in turn increases innovation. Subsequently, through other paper we will empirically test this model within the Egyptian banking sector as one of the emerging markets.

\section{CONCLUSION, LIMITATIONS, AND FUTURE RESEARCH}

\section{Conclusion}

Strategic HRM is the new paradigm to manage the people in the modern of the organizations to link between HRM and strategic objectives. In contrast, innovation and intellectual capital are major resources to survive of organization and achieve a competitive position. In light of an extensively SHRM literature review, indicates the results that the researchers examined the relationship between strategic HRM and performance in the different ways and within different contexts. Hence, this paper adds to the existing strategic HRM literature by explaining the role of strategic HRM in development of intellectual capital and creating innovation and finally develop a conceptual model to explore the role mediator of intellectual capital in explaining the relationship between strategic HRM and innovation performance.

\section{Limitations of Study}

Two main limitations are in this study, the first; we are not getting into detail related to the systematic perspective of SHRM such as (best practice, contingency and configurational approach) (Wright \& Ulrich, 2017, P4). And we focused only on two dimensions of strategic HRM to represent the strategic perspective (strategic alignment of HRM and strategic HR orientation). Secondly; the emphasis was given only to one of the performance outcomes (innovation) and we ignored the other outcomes (e.g. productivity and profitability)

\section{Future Research}

Given the importance of strategic HRM as an approach to achieve an organization's strategic objectives and improve performance, more research must be undertaken regarding the strategic perspective to SHRM (e.g. strategic alignment of HRM, strategic HR orientation, strategic HR devolvement and the interaction between HRM strategies and organization strategies). As well as examining the role these mechanisms work to gain competitive advantage and improve organizational outcomes such as (productivity, innovation and quality... etc). Also, further contributions need to be provided regarding the black box concept in SHRM domain via examine variables (e.g. dynamic capabilities and innovation culture) as intermediating variables.

\section{References}

Abdal, M., Alzuod, K., Faizal, M., Isa, M., Zubaidah, S., \& Othman, B. (2017). Intellectual Capital, Innovative Performance and the Moderating Effect of Entrepreneurial Orientation among Small and Medium- sized Enterprises in Jordan. International Review of Management and Marketing, 7(2), 308-314. 
International Journal of Business and Management Review

Vol.8, No.5, pp.44-67, August 2020

Published by ECRTD-UK

Print ISSN: 2052-6393(Print), Online ISSN: 2052-6407(Online)

Agostini, L., Nosella, A., \& Filippini, R. (2017). Does intellectual capital allow improving innovation performance? A quantitative analysis in the SME context. Journal of Intellectual Capital, 18(2), 400-418.

Allameh, S. M. (2018). Antecedents and consequences of intellectual capital The role of social capital , knowledge sharing. Journal of Intellectual Capital, 19(5), 858-874.

Allui, A., \& Sahni, J. (2016). Strategic Human Resource Management in Higher Education Institutions: Empirical Evidence from Saudi. Procedia - Social and Behavioral Sciences, 235(10), 361-371.

Andersen, K. K., Cooper, B. K., \& Zhu, C. J. (2007). The effect of SHRM practices on perceived firm financial performance: Some initial evidence from Australia. Asia Pacific Journal of Human Resources, 45(2), 168-179.

Andreeva, T., Garanina, T., \& Andreeva, T. (2016). Do all elements of intellectual capital matter for organizational performance? Evidence from Russian context. Journal of Intellectual Capital, 17(2), 397-412.

Arunprasad, P. (2017). Inevitable knowledge strategy: A paradigm shift in strategic HRM practices to augment firm's performance. Employee Relations, 39(5), 753-774.

Aryanto, R., Fontana, A., \& Afiff, A. Z. (2015). Strategic Human Resource Management, Innovation Capability and Performance: An Empirical Study in Indonesia Software Industry. Procedia - Social and Behavioral Sciences, 211, 874-879.

Bal, Y. (2013). A study on determining the relationship between strategic HRM practices and creating innovation in organizations. International Journal of Contemporary Management, 9(13), 1-14.

Barney. (1991). Firm resources and sustained competitive advantage. Journal of Management, Vol. 17, pp. 99-120.

Becker, B. E., \& Huselid, M. A. (2006). Strategic human resources management: Where do we go from here? Journal of Management, 32(6), 898-925.

Boon, C., Eckardt, R., Lepak, D. P., Boselie, P., Boon, C., Eckardt, R., ... Integrating, P. B. (2018). Integrating strategic human capital and strategic human resource management. The International Journal of Human Resource Management, 5192, 134.

Budhwar, P. S. (2000). Strategic Integration and Devolvement of Human Resource Management in the UK Manufacturing Sector. British Journal of Management, 11, 285-302.

Cabello-medina, C., López-cabrales, Á., \& Valle-, R. (2011). Leveraging the innovative performance of human capital through HRM and social capital in Spanish firms. The International Journal of Human Resource Management, 37-41.

Ceylan, C. (2013). Commitment-based HR practices, different types of innovation activities and firm innovation performance. International Journal of Human Resource Management, 24(1), 208-226.

Chahal, H., \& Bakshi, P. (2015). Examining intellectual capital and competitive Role of innovation and organizational learning. International Journal of Bank Marketing, 33(3), 376-399.

Chen, C. J., \& Huang, J. W. (2009). Strategic human resource practices and innovation 
International Journal of Business and Management Review

Vol.8, No.5, pp.44-67, August 2020

Published by ECRTD-UK

Print ISSN: 2052-6393(Print), Online ISSN: 2052-6407(Online)

performance - The mediating role of knowledge management capacity. Journal of Business Research, 62(1), 104-114.

Chowhan, J. (2016). Unpacking the black box: understanding the relationship between strategy, HRM practices, innovation and organizational performance. Human Resource Management Journal, 26(2), 112-133.

Delery, J. E., \& Roumpi, D. (2017). Strategic human resource management, human capital and competitive advantage: is the field going in circles? Human Resource Management Journal, 27(1), 1-21.

Delgado-Verde, M., Martín-De Castro, G., \& Amores-Salvadó, J. (2016). Intellectual capital and radical innovation: Exploring the quadratic effects in technology-based manufacturing firms. Technovation, 54, 35-47.

Donate, M. J., Peña, I., \& Pablo, J. D. S. De. (2015). HRM practices for human and social capital development : effects on innovation capabilities. The International Journal of Human Resource Management, (July 2015), 1-21.

Duanxu, W., Shuai, C., Wang, D., \& Chen, S. (2013). Does intellectual capital matter? High-performance work systems and bilateral innovative capabilities.

Dženopoljac, V., Janoševic, S., \& Bontis, N. (2016). Intellectual capital and financial performance in the Serbian ICT industry. Journal of Intellectual Capital, 17(2), 373396.

Ekhsan Abang Othman, A. (2009). Strategic integration of human resource management practices Perspectives of two major Japanese in Malaysia. Cross Cultural Management: An International Journal, 16(2), 197-214.

Fahim, M. G. A. (2018). Strategic human resource management and public employee retention. Review of Economics and Political Science, 3(2), 20-39.

Farouk, S., Elanain, H. M. A., Obeidat, S. M., \& Al-nahyan, M. (2016). HRM practices and organizational performance in the UAE banking sector The mediating role of. International Journal of Productivity and Performance Management, 65(6), 731791.

Fu, N., Flood, P. C., Bosak, J., Morris, T., \& O'Regan, P. (2015). How do high performance work systems influence organizational innovation in professional service firms? Employee Relations, 37(2), 209-231.

Gannon, J. M., Roper, A., \& Doherty, L. (2015). Strategic human resource management: Insights from the international hotel industry. International Journal of Hospitality Management, 47, 65-75.

Gautam, D. K. (2015). Strategic integration of HRM for organizational performance: Nepalese reality. South Asian Journal of Global Business Research, 4(2015), 110128.

Green, K. W., Wu, C., Whitten, D., \& Medlin, B. (2006). The impact of strategic human resource management on firm performance and HR professionals' work attitude and work performance. International Journal of Human Resource Management, 17(4), $559-579$.

Gurbuz, S., \& Mert, I. S. (2011). Impact of the strategic human resource management on organizational performance: Evidence from Turkey. International Journal of Human 
International Journal of Business and Management Review

Vol.8, No.5, pp.44-67, August 2020

Published by ECRTD-UK

Print ISSN: 2052-6393(Print), Online ISSN: 2052-6407(Online)

Resource Management, 22(8), 1803-1822.

Hanifah, H., Halim, H. A., Ahmad, N. H., \& Vafaei-zadeh, A. (2019). Can internal factors improve innovation performance via innovation culture in SMEs? Benchmarking: An International Journal.

Haque, A. (2018). Strategic Human Resource Management and Presenteeism : Conceptual Framework to Predict Human Resource Outcomes. New Zealand Journal of Human Resources Management, (2018).

Hui-Ying Zhang, S. L. (2015). Intellectual Capital and Technological Innovation: The Mediating Role of Supply Chain. International Journal of Innovation Science, 7(3), 199-210.

Hussinki, H., Ritala, P., Vanhala, M., \& Kianto, A. (2017). Intellectual capital, knowledge management practices and firm performance. Journal of Intellectual Capital, 18(4), 904-922.

Iqba, A. (2018). The strategic human resource management approaches and organisational performance The mediating role of creative climate. Journal of Advances in Management Research.

Jiang, J., Wang, S., \& Zhao, S. (2012). Does HRM facilitate employee creativity and organizational innovation? A study of Chinese firms. The International Journal of Human Resource Management, 23(11), 37-41.

Jiang, K., Lepak, D. D., Hu, J., \& Baer, J. C. (2012). How Does Human Resource Management Influence Organization Outcomes? A Meta-Analytic Investigation Of mediating Mechanisms. Academy of Management Journal, 55(6), 1264-1294.

Jiang, K., Takeuchi, R., \& Lepak, D. P. (2013). Where do we go from here? New perspectives on the black box in strategic human resource management research. Journal of Management Studies, 50(8), 1448-1480.

Jiuhua, C., Cooper, B. K., \& Bruce, S. (2013). Strategic integration of HRM and firm performance in a changing environment in China: the impact of organisational effectiveness as a mediator. The International Journal OfHuman Resource Management, 24(15), 2985-3001.

John E. Delery, J. D. S. (2015). The strategic management of people in work organizations: Review, synthesis, and extension. Research in Personnel and Human Resources Management, 8(3), 1-46.

Jonc, J. A. (2015). The impact of human resource management on the innovativeness of public hospitals in Poland. Procedia - Social and Behavioral Sciences, 213, 10001007.

Junita, A. (2016). The Interaction between Human and Organizational Capital in Strategic Human Resource Management. International Research Journal of Business Studies, 9(1), 49-62.

Kalkan, A., Bozkurt, Ö. Ç., \& Arman, M. (2014). The Impacts of Intellectual Capital, Innovation and Organizational Strategy on Firm Performance. Procedia - Social and Behavioral Sciences, 150, 700-707.

Karchegani, M. R., Sofian, S., \& Amin, S. M. (2013). The relationship between intellectual acpital and innovation; A Review. International Journal of Business and 
International Journal of Business and Management Review

Vol.8, No.5, pp.44-67, August 2020

Published by ECRTD-UK

Print ISSN: 2052-6393(Print), Online ISSN: 2052-6407(Online)

Management Studies, 2(1)(2014), 561-581.

Katou, A. A. (2017). How does human resource management influence organisational performance? An integrative approach-based analysis. International Journal of Productivity and Performance Management, 66(6), 797-821.

Kong, E., \& Thomson, S. B. (2006). Intellectual capital and strategic human resource management in social service non-profit organisations in Australia. Int. J. Human Resources Development and Management, 6(11), 213-231.

Loshali, S., \& Krishnan, V. R. (2013). Strategic Human Resource Management and Firm Performance : Mediating Role of Transformational Leadership. Journal of Strategic Human Resource Management Human, 2(2/ 2013).

Lu, K., Zhu, J., \& Bao, H. (2015). High-performance human resource management and firm performance: The mediating role of innovation in China. In Industrial Management and Data Systems (Vol. 115).

Madera, J. M., Dawson, M., \& Guchait, P. (2016). Strategic human resources management research in hospitality and tourism suggestions for the future.

Martinson, B., \& De Leon, J. (2018). Testing horizontal and vertical alignment of HR practices designed to achieve strategic organizational goals. Journal of Organizational Effectiveness, 5(2), 158-181.

McDowell, W. C., Peake, W. O., Coder, L. A., \& Harris, M. L. (2018). Building small firm performance through intellectual capital development: Exploring innovation as the "black box." Journal of Business Research, 88(2), 321-327.

Messersmith, J. G., Lepak, D. P., \& Gould-williams, J. S. (2011). Unlocking the Black Box : Exploring the Link Between High-Performance Work Systems and Performance. Journal of Applied Psychology, 96(6), 1105-1118.

Michael Armstrong. (2009). Handbook Of Human Resource Management Practice (11TH EDITI). London and Philadelphia.

Mir Dost, Yuosre F. Badir, Zeeshan Ali, A. T. (2016). The impact of intellectual capital on innovation generation and adoption. Journal of Intellectual Capital, 17(4), 675-695.

Naitore, D. (2019). Strategic Human Resource Management Practices on Performance in selected public Universies in Kenya. International Academic Journal of Human Resource and Business Administration, 3(5), 1-19.

Nigam, A. K., Nongmaithem, S., Sharma, S., \& Tripathi, N. (2011). The impact of strategic human resource management on the performance of firms in India A study of service sector firms. Journal of Indian Business Research, 3(3), 148-167.

Omerzel, D. G., \& Jurdana, D. S. (2016). The influence of intellectual capital on innovativeness and growth in tourism SMEs : empirical evidence from Slovenia and Croatia. Economic Research-Ekonomska Istraživanja, 9664, 1-16.

Ozkan, N., Cakan, S., \& Kayacan, M. (2017). Intellectual capital and financial performance: A study of the Turkish Banking Sector. Borsa Istanbul Review, 17(3), 190-198.

Paauwe, J. (2009). HRM and Performance: Achievements ,. (January).

Patrick M. Wright; Gary C. McMahan. (2011). Exploring human capital: putting human back into strategic human resource management. Human Resource Management Journal, 21(2), 93-104. 
International Journal of Business and Management Review

Vol.8, No.5, pp.44-67, August 2020

Published by ECRTD-UK

Print ISSN: 2052-6393(Print), Online ISSN: 2052-6407(Online)

Peccei, R. (2019). The Application of the Multilevel Paradigm in Human Resource Management - Outcomes Research : Taking Stock and Going Forward (Vol. 45).

Pedro, E., Leitão, J., \& Alves, H. (2018). Intellectual capital and performance: Taxonomy of components and multi-dimensional analysis axes. Journal of Intellectual Capital, $19(2), 407-452$.

Qadeer, F. (2018). Antecedents of Transition towards Strategic HRM in Developing Countries Faisal Qadeer and Saad Hussain. Asian Management Research Journal, $1(1), 1-21$.

Renkema, M., Meijerink, J., \& Bondarouk, T. (2017). Human Resource Management Review Advancing multilevel thinking in human resource management research: Applications and guidelines. Human Resource Management Review, 1-19.

Rezende, J. F., Correia, A. A., \& Gomes, B. A. (2017). The intellectual capital and the creation of value in research units linked to the Brazilian Ministry of Science Technology and Innovation. RAI Revista de Administração e Inovação, 14(3), 199215.

Saridakis, G., Lai, Y., \& Cooper, C. L. (2016). Human Resource Management Review Exploring the relationship between HRM and fi rm performance: A meta-analysis of longitudinal studies. Human Resource Management Review.

Schuler, R. S., \& Jackson, S. E. (2005). A Quarter-Century Review of Human Resource Management in the $\mathrm{U} . \mathrm{S}:$ The Growth in Importance of the International Perspective. Management Revue, 16(1).

Shaw, J. D., Park, T., \& Kim, E. (2013). A resources-based perspective on human capital losses, HRM investments, and organization performance. Strategic Management Journal, 589(2012), 572-589.

Singh, K. (2003). Strategic HR orientation and firm performance in India. International Journal of Human Resource Management, 14(4), 530-543.

Singh, N. (2018). Strategic human resource practices for innovation performance An empirical investigation. Benchmarking: An International Journal, 25(9), 3459-3478.

Singh, S., Darwish, T. K., Costa, A. C., \& Anderson, N. (2012). Measuring HRM and organisational performance: Concepts, issues, and framework. Management Decision, 50(4), 651-667.

Sözbilir, F. (2018). The interaction between social capital, creativity and efficiency in organizations. Thinking Skills and Creativity, 27(2017), 92-100.

Susan, B., Saeed, R., Mohammad, H. Y., \& Hassan, A. B. N. (2013). Simple and multiple relations between strategic human resource management and intellectual capital in Iranian higher education. African Journal of Business Management, 7(35), 34513460.

Syed Akhtar, Daniel Z. Ging, and G. L. G. (2008). Strategic HRM Practices and Their Impact on Company Performance In Chinse Enterprises. Human Resource Management, 47(11), 15-32.

Tamer Khalil Darwish, S. S. (2013). Does strategic human resource involvement and devolvement enhance organisational performance? Evidence from Jordan. International Journal of Manpower, 34(6), 674-692. 
International Journal of Business and Management Review

Vol.8, No.5, pp.44-67, August 2020

Published by ECRTD-UK

Print ISSN: 2052-6393(Print), Online ISSN: 2052-6407(Online)

Tarhini, A., \& Student, M. B. A. (2017). The impact of intellectual capital on innovation via the mediating role of knowledge management: a structural equation modelling approach Bader Yousef Obeidat. Int. J. Knowledge Management Studies, 8, 273298.

Waiganjo, E. W., Kahiri, J., \& Ph, D. (2012). Relationship between Strategic Human Resource Management and Firm Performance of Kenya's Corporate Organizations School of Human Resource Development. International Journal of Humanities and Social Science, 2(10), 62-70.

Wan-Jing April Chang, T. C. H. (2005). Relationship between strategic human resource management and firm performance A contingency perspective. International Journal of Manpower, 26(5), 434-449.

Wang, D., \& Chen, S. (2013). Does intellectual capital matter? High-performance work systems and bilateral innovative capabilities. International Journal of Manpower, 34(8), 861-879.

Wang, Z., Wang, N., Cao, J., \& Ye, X. (2016). The impact of intellectual capital - knowledge management strategy fit on firm performance. Management Decision, 54(8), 18611885.

Way, S. A., \& Johnson, D. E. (2005). Theorizing about the impact of strategic human resource management. Human Resource Management Review, 15, 1-19.

Wendra , Ernie Tisnawati , Joeliaty, Y. A. (2019). Exploring dynamic capabilities, intellectual capital and innovation performance relatinship; evidence from the Garment manufacturing. Business; Theory and Practice, 123-136.

Wright, P.M., and McMahan, G. C. (1992). 'Theoretical Perspectives for Strategic Human Resource Management,.' Journal of Management, 18, 2, 295-320.

Wright, P. M., Dunford, B. B., \& Snell, S. A. (2001). Human resources and the resource based view of the firm. Journal of Management, 27, 701-721.

Wright, P. M., Gardner, T. M., \& Moynihan, L. M. (2003). performance of business units. Hunan Resource Managemnt Journal, 13(3), 21-36.

Wright, P. M., Nyberg, A. J., \& Ployhart, R. E. (2018). A Research Revolution in SHRM: New Challenges and New Research Directions. Research in Personnel and Human Resources Management, 141-161.

Wright, P. M., \& Ulrich, M. D. (2017). A Road Well Traveled: The Past, Present, and Future Journey of Strategic Human Resource Management. Annual Review of Organizational Psychology and Organizational Behavior, 1-23.

Yaseen, S. G., Dajani, D., \& Hasan, Y. (2016). The impact of intellectual capital on the competitive advantage: Applied study in Jordanian telecommunication companies. Computers in Human Behavior, 62, 168-175.

Youndt, M. A., Subramaniam, M., \& Snell, S. A. (2004). Intellectual Capital Profiles: An Examination of Investments and Returns. Journal of Management Studies, 41(2), 335-361.

Yuqian Han, D. L. (2015). Effects of intellectual capital on innovative performance The role of knowledge-based. Management Decision, 53(1), 40-56.

Zehir, C., Gurol, Y., Karaboga, T., \& Kole, M. (2016). Strategic Human Resource 
International Journal of Business and Management Review Vol.8, No.5, pp.44-67, August 2020

Published by ECRTD-UK

Print ISSN: 2052-6393(Print), Online ISSN: 2052-6407(Online)

Management and Firm Performance: The Mediating Role of Entrepreneurial Orientation. Procedia - Social and Behavioral Sciences, 235, 372-381.

Zehir, C., Üzmez, A., \& Yıldız, H. (2016). The Effect of SHRM Practices on Innovation Performance: The Mediating Role of Global Capabilities. Procedia - Social and Behavioral Sciences, 235, 797-806. 